\title{
The Number of Albatross (Diomedeidae) Species
}

\author{
John Penhallurick*
}

86 Bingley Cres., FRASER, A.C.T. 2615, Australia

\begin{abstract}
The basis of the widespread practice of recent years to recognise 23 or 24 species of albatross is critically examined. In large part this can be traced back to an analysis which split the traditional species of albatross on the basis of theoretical fiat: the embrace of the narrow Phylogenetic Species Concept. The role of conservation concerns in albatross taxonomy is examined and rejected. Claims that introgression is likely to explain the low cytochrome- $b$ distance found between many "new" albatross species are rejected. An analysis of climatic conditions at albatross breeding colonies can explain plumage differences in the ontogeny of albatross taxa, and plumage colouration can be related to differing environmental pressures. It is concluded that the variation among taxa within albatross taxa is ecophenotypic. Finally, it is suggested that a plausible mechanism for such variation can be found in epigenetics.
\end{abstract}

Keywords: Albatrosses, taxonomy, ontogeny, ecophenotypic variation, epigenetics, suggested.

\section{INTRODUCTION}

Using the Phylogenetic Species Concept (PSC), Robertson \& Nunn [1] split the then widely accepted 13 albatross (Procellariiformes: Diomedeidae) species into 24 species. The data upon which Robertson \& Nunn [1] based this treatment were cytochrome- $b$ sequences generated by Nunn et al. [2] to examine the species and generic level phylogenetic relationships within members of the albatross family. Nunn et al. [2] found that the genus Diomedea Linnaeus 1758 was paraphyletic, and proposed to recognize four genera: Diomedea sensu stricto; Thalassarche Reichenbach, 1853; and Phoebastria Reichenbach, 1853, beside Phoebetria Reichenbach,1853. Pairwise cytochrome- $b$ distances within the genera ranged from $1.66 \%$ to $4.72 \%$ : Diomedea sensu stricto 3.15\%; Thalassarche 3.15\%-1.66\%; Phoebastria $4.72 \%-1.75 \%$. Nunn et al [2] did not comment on or discuss pairwise distances at the subspecific level, which ranged below $1.1 \%$. The distances between members of the three genera were much greater ( $9.89 \%$ to $11.20 \%$ ). Robertson \& Nunn [1] ignored the low intrageneric genetic distances, and accepted the PSC in delineating species limits. Their species-level treatment has since been widely accepted.

\section{WIDESPREAD ACCEPTANCE OF ROBERTSON \& NUNN'S (1998) ANALYSIS}

Problems with the PSC have been pointed out in numerous sources, including Penhallurick \& Wink [3] and Haffer [4]. Nevertheless, in recent years, several sources generally treated as authoritative, and which generally adopt the multidimensional Biological Species Concept (mBSC Mayr [5]), notably the IOC World List [6] and BirdLife International $[7,8]$ have accepted, to a greater degree, the multiplication of albatross species. In Table $\mathbf{1}$, the treatment of albatrosses

*Address correspondence to this author at the 86 Bingley Cres., FRASER, A.C.T. 2615, Australia; Tel: (612) 62585428;

E-mail: jpenhall@bigpond.net.au in a number of recent sources is compared. However, recent Australian authorities, such as Christidis \& Boles [9], and following them, the Australian Government Department of the Environment, Water, Heritage and the Arts [10] have rejected Robertson \& Nunn's [1] approach. Christidis \& Boles [9: 86] stated that the PSC approach treated species taxa which differ markedly in terms of their level of genetic differentiation; and specifically the genetic distances between conventional species which were much greater than those between conventional subspecies. These differences suggested to them two distinct tiers of differentiation.

Another factor in the acceptance of Robertson \& Nunn's [1] analysis was the fact that it coincided with increasing, and justified, concern about threats to the survival of many albatross taxa, particularly from long-line fishing. The conservation policies of many governments are thought to be defined in terms of the conservation of "species". Certainly, conservation values have been a factor in the acceptance of far more than the traditionally accepted 13 species: it is perhaps significant that two concepts utilized in some of the recent papers on albatross species have used the terms "management units" (MU) and "evolutionary significant units" (ESU), both of which suggest conservation concerns.

In addition, two papers (Navarro-Sigüenza \& Peterson [12] and Rojas-Salto et al. [13]) have made their preference explicit for the PSC over on the mBSC solely the basis that this will allow more taxa to be count as endangered to some degree and thus qualify for government protective action. Yet Garnett \& Christidis [14] have suggested that most laws and international conventions avoid arguments over species' definitions altogether, thus negating arguments that such definitions should be changed to further species' conservation.

In this paper, support is given to the analysis of albatross species in Penhallurick \& Wink [3]. Below, it will be recommended that in accordance with the mBSC, there are 12 species of albatross, although this account will differ slightly from the traditional account. Specifically, Diomedea amster- 
Table 1. Accounts of Albatross Taxa in Traditional Terms and in Four Recent Sources: (Robertson \& Nunn [1]; ACAP [11]; IOC [6]; BirdLife International. [7, 8]

\begin{tabular}{|c|c|c|c|c|}
\hline Traditional Taxa & Robertson \& Nunn & IOC's Account & ACAPs' Account & BirdLife International \\
\hline D. e. exulans & D. exulans & D. exulans & D. exulans & D. exulans \\
\hline D.e. antipodensis & D. antipodensis & D. a.antipodensis & D. a.antipodensis & D. a.antipodensis \\
\hline D. e. gibsoni & D. gibsoni & D. a. gibsoni & D. a. gibsoni & D. a. gibsoni \\
\hline D. e. sanfordi & D. sanfordi & D. sanfordi & D. sanfordi & D. sanfordi \\
\hline T. m. melanophris & T. melanophris & T. melanophris & T. melanophris & T. melanophris \\
\hline T. m. impavida & T. impavida & T. impavida & T. impavida & T. impavida \\
\hline T. c. cauta & T. cauta & T. cauta & T. cauta & T. cauta \\
\hline T. c. salvini & T.salvini & T. salvini & T. salvini & T. salvini \\
\hline T. c. chlororhynchos & T. chlororhynchos & T. chlororhynchos & T. chlororhynchos & T. chlororhynchos \\
\hline T. c. carteri & T. carteri & T. carteri & T. carteri & T. carteri \\
\hline
\end{tabular}

damensis Roux et al., [15], which was originally described as a good species, will be considered a subspecies of $D$. exulans. (see also Christidiis and Boles [9]).

\section{SOURCES CITED AS SUPPORTING GREATER NUMBERS OF ALBATROSS SPECIES}

As authorities for its changes, the IOC World List [6] gives a list of sources, including: Tickell [16]; Brooke [17]; and Onley [18]. BirdLife International [7, 8] likewise cites only Brooke [17] and Robertson \& Nunn [1] as taxonomic authorities. In Tickell [16], in Chapter 5, Mollymawks, the author offers readers their own choice between the biological species concept, with five species, and the phylogenetic species approach, with eleven. Similarly in Appendix I, the reader is offered a choice between the two approaches. In summary, Tickell [16] merely notes the existence of two accounts but does not make a choice one way or the other. There is little discussion of taxonomy in Brooke [17]. Onley [18] stated that in terms of taxonomy, he followed Brooke [17]. He also cited Burg \& Croxall [19] and Burg \& Croxall [20].

All told, the books considered so far provide little evidence that they can be considered as taxonomically authoritative. So we need to consider some of the publications in refereed journals. Rheindt \& Austin [21], in criticizing Penhallurick \& Wink [3], cite specifically Abbott \& Double $[22,23]$; and Burg \& Croxall $[19,20]$ as studies that have uncovered "new evidence for the species status of at least some of the albatrosses". But nothing in Abbott \& Double's two papers is relevant to the question addressed here: should a number of taxa traditionally treated as subspecies within a single species be treated as comprising two or more species in terms of the mBSC. Of critical importance, in this discussion are, the species concepts utilized in these studies.

Abbott \& Double [22] initially stated that they were adopting the species nomenclature suggested by Robertson \& Nunn [1]. In their abstract, Abbott \& Double [22] stated that their analysis confirmed the separation of the shy/whitecapped pair and the Salvin's/Chatham pair but did not provide species-level resolution (Emphasis added). Abbott \& Double [23] dealt with the Shy Albatross (Thalassarche cauta Gould, 1841) and White-capped Albatross (Thalassarche steadi Falla, 1933) and reported levels of genetic differentiation between the species, and among three populations within each species. However, there is in fact no evidence brought forward in the paper as to whether these taxa should be treated at the species or subspecies level. They recommended that the three white-capped albatross populations and each shy albatross population be treated as separate units for conservation. Burg \& Croxall [19] dealt with the relationships and classification of Grey-headed Albatross Thalassarche chrysostoma (J. R. Forster 1785) and Blackbrowed Albatross Thalassarche melanophris, and specifically the relationship between Thalassarche melanophris melanophris and Thalassarche melanophris impavida Mathews,1912. In terms of what species concept they were using, they cite Moritz [24,25], who described the differences between management units (MU) and evolutionary significant units (ESU): ESUs are two groups that show reciprocal monophyly of mtDNA haplotypes and significant differences in allele frequencies at nuclear loci. MUs, on the other hand, show significant differences in allele frequencies without regard to the phylogeny of the markers. They also cite Avise \& Wollenberg [26], who endorsed the Phylogenetic Species Concept (PSC) which emphasizes on the crite- 
ria of phylogenetic relationships and not reproductive relationships. Thus, it appears that they are using either the ESU model, which stresses conservation values, or the PSC1, which treats all subspecies as species. If this analysis is correct, this paper cannot be considered as establishing valid species status in terms of the mBSC for any of the group they discuss. Furthermore, Christidis \& Boles [9: 87] stated that Burg \& Croxall [19] compared their data with other studies examining control region divergences in avian species and subspecies, but again these comparisons are limited in their instructiveness because different parts of the control region evolve at markedly different rates. (see also Howell et al. [27], dealing with relative rates of evolution in the coding and control regions of African human DNA). Burg \& Croxall [21] targeted a small, rapidly evolving section of the control region, but compared their results with some other studies that sampled complete or near complete control regions, including both highly conserved and variable regions. Such a comparison is invalid, comparing like with unlike.

The IOC Worldlist [6] also cites Burg \& Croxall [20], who focused on the Wandering Albatross species complex. Burg \& Croxall [20] stated that differences in the frequency of a single restriction site were detected using random fragment length polymorphism. Microsatellite analyses using nine variable loci showed that $D$. exulans, $D$. antipodensis and $D$. gibsoni were genetically differentiated. Despite the widespread distribution of $D$. exulans, they did not detect any genetic differentiation among populations breeding on different island groups. The lower level of genetic differentiation between $D$. antipodensis and $D$. gibsoni should lead to their reclassification as D. $a$. antipodensis and D. $a$. gibsoni. They argued that, within the context of the current taxonomy, these combined data support three species: $D$. dabbenena, $D$. exulans and $D$. antipodensis.

What Burg \& Croxall's [20] case amounts to is that the number of differing alleles in the 234 base pair region of the hypervariable portion of the control region (Domain I) is significantly higher in the case of most different taxa than within members of the same taxon (and between $D$. antipodensis and $D$. gibsoni). There is certainly no generally accepted principle in ornithology which states that within a species complex, only the two most similar taxa should be considered as subspecies of a species-level taxon. The new metric for speciation presented by Burg \& Croxall [20] requires calibration: notably between the same regions in a traditionally different species, such as $D$. epomophora and D. exulans. Thus, we find Tobias et al. [28] stating that comparing molecular divergence with that found between irrefutable species is clearly useful in as much as it gives a rough indication of how likely it is that reproductive incompatibilities have evolved between two taxa. Such a measure is not provided in Burg \& Croxall [20]. A recent publication (Rains et al. [29]) dealing with the "Amsterdam" Albatross has repeated the mistakes of Burg \& Croxall's papers [19] and [20]. Early in the paper we have told that cyt- $b$ may not be the optimal marker to detect genetic differences between populations as cyt- $b$ evolves more slowly, whereas control region DNA is noncoding and evolves at a faster rate and, thus, is much more informative. In other words, if a standard metric fails to give the results the researchers want, they decide to use a different one. Once again, they restricted their study to the highly variable portion of the Control Region. And they made comparisons only with three other members of the Diomedea exulans complex: $D$. exulans, $D$. antipodensis and $D$. dabbenena. All they showed is that there are variable levels of genetic differentiation among the four taxa. This is exactly what analyses based on cytochrome- $b$ have shown, and to repeat an earlier point, merely showing genetic differentiation among taxa does not, with the mBSC, itself proves that they should automatically be treated as different at the specific level.

It was mentioned above that until recently, there was universal agreement that no splits were postulated in the genera Phoebastria Reichenbach, 1853 or Phoebetria Reichenbach, 1853. However, Eda et al. [30] have postulated two distinct species of Short-tailed Albatross Phoebastria albatrus. Once again, they have used the hypervariable CD2 region from the control region. And they justify their claim that two species should be recognized by comparing the CR2 distances for $P$. albatrus with those for CR1 between some taxa within Diomedea and some taxa within Thalassarche (see Burg \& Croxall[19 and 20]; and Rains et al.[29]). Eda et al stated: "These facts suggest that individuals having mtDNA belonging to the same haplotypic clade formed a different population about 1,000 years ago, and they strongly support a historical scenario explaining the modern genetic structure: the co-occupation of populations isolated for long periods of time.” This must set a new record for time needed for distinct species to develop.

Another recent source of controversy has been a proposal submitted to the South American Checklist Committee (SACC): Proposal 388, by Frank Rheindt, which is to "split Diomedea exulans into four species" (Remsen [31]). Rheindt put forward three options: 1 . One species: lump all five taxa into $D$. exulans this is the status quo. 2. Four species: recognize all taxa as distinct species, except for gibsoni, which is retained in D. antipodensis. This is Burg \& Croxall's [20] proposal; 3. Five species: recognize all taxa as distinct species. This was Robertson \& Nunn's [1] treatment.

Rheindt continued that as far as Options 1 and 2 are concerned, he did not feel that there is overwhelming evidence for either treatment. However, if he were forced to make a recommendation, he would advocate Option 2, because distributional data indicate that the New Zealand taxa do not interbreed with exulans even though they could (Emphasis added). By yardstick analogy, the temperate-zone dabbenena (which may have a different life-history owing to its warmcurrent environment) would be at the species level because its control-region differentiation towards the other taxa is even more pronounced than that of the New Zealand clade (Burg \& Croxall [20]). Data on the extralimital amsterdamensis are lacking, but on account of its high level of morphological differentiation (=extreme neoteny) it may be best to go with the describers' recommendation for species status (Roux et al. [15]) until and unless other data have been presented. In essence, the case made by Rheindt in favor of option 2 amounts to two arguments. (1) the settlement of a small numbers of pairs of $D$. exulans [about 10 breeding pairs currently] on Macquarie Island amounts to evidence of reproductive isolation from the taxa breeding on the New Zealand subantarctic islands. (2) that introgression may be a 
significant factor in the relatively low mtDNA distances between the taxa in the exulans complex.

The first reason strikes one as unimpressive. There is a clear difference between the breeding range of nominate exulans and that of all other taxa in the complex. The breeding range of nominate exulans is south of the Antarctic Convergence (South Georgia); on the Antarctic Convergence (Kerguelen Archipelago); or just north of the Convergence (Iles Crozet, Marion Island, Prince Edward Island; Macquarie Island). The breeding range of all the other taxa within the $D$. exulans complex is well north of that convergence. There are major differences in the climate of the islands involved. The mean annual temperature (from $1.7^{\circ} \mathrm{C}$ on South Georgia to $4.8^{\circ} \mathrm{C}$ on the Iles Crozet) and in particular the mean temperature during months of breeding is significantly lower for the islands on which the nominate taxon breeds than for those on which all other taxa in the complex breed (e.g. from $6{ }^{\circ} \mathrm{C}$ on Campbell Island to $13^{\circ} \mathrm{C}$ on Amsterdam Island). Given the marked contrast in the breeding climates of exulans and others, particularly the populations breeding on New Zealand subantarctic islands, it is very unlikely that any members of exulans would try to breed on the more northerly islands, or that members of gibsoni or antipodensis or amsterdamensis would attempt to breed much closer to, let alone below, the Antarctic Convergence. Thus, Rheindt was incorrect in saying that taxa could interbreed solely on the basis of distance. We will see below that the different plumages of members of the exulans complex can be explained in terms of the climate differences just referred to.

If we move on to Rheindt's second point: that the low mtDNA distances between taxa in the Wandering Albatross complex may be a result of introgression: the usual way to demonstrate that introgression has occurred is to show that (usually) two taxa share unique haplotypes. Thus far, no one has shown evidence of such sharing. Rheindt replied to my criticisms of his appeal to possible introgression as an explanation for the low sequence distances between members of the exulans complex by stating that MtDNA introgression is pervasive in the biological world and greatly diminishes the utility of low mtDNA divergences as a true yardstick of taxon divergence. Secondly, he claimed that mtDNA introgression can affect all/most members of entire radiations, such as Anas ducks (Johnson \& Sorenson [32]) and Larus gulls (Liebers et al. [33]). Thirdly, he stated that genetic introgression can be extremely fast. For an avian example, take Mank et al.'s [34] research showing how Mottled Duck and Mallard microsatellites went from distinct to almost identical within only 58 years. It is interesting that Rheindt chooses to ducks and gulls for his examples of extensive and fast introgression. In both these families, hybrids are common and obvious. But no-one has ever knowingly seen or collected a hybrid albatross from the exulans complex, and given their philopatry and strictly allopatric distribution, it is hard to imagine how such hybridization involving all members of the complex could occur. Limited hybridization has occurred between Thalassarche m. melanophris and T. m. impavida on Campbell Island, but as it will be stated below, the taxonomic significance of this is debatable.
Before leaving the discussion of Proposal 388, notice should be taken of a contribution by J. P. Croxall. It included a statement that findings of Chambers et al. [35] support the proposal to split $D$. exulans into four species. But what Chambers et al. [35] actually said in their paper is the reverse of what Croxall claimed. They adopt the $1 \%$ species level characteristic of barcoding (Stoeckle [36], Edwards [37]). Thus Chambers et al. [35] rejected the split between Diomedea epomophora and D. sanfordi, and also rejected splits within the Diomedea exulans complex. If one turns to the proposed splits within Thalassarche: Chambers et al. [35] rejected the split between T. chlororhynchos [sic for chlororhynchus by Chambers et al. [35]] and T. carteri, since their cytochrome- $b$ distance is only $0.4 \%$. They also reject any suggestions of splitting the two taxa in Buller's Albatross, T. b. bulleri and T. sp.nov. (called platei by Chambers et al. [35]. But Robertson \& Nunn [1: 18] stated that platei Reichenow, 1898 should be reduced to a synonym, being just a juvenile plumage phase of $T$. bulleri.). The final position on T. melanophris [melanophrys [sic] by Chambers et al. [35]] and T. impavida is unclear. Despite the fact that the cytochrome- $b$ sequences differ by $0.8 \%$ between these two species, they considered them to have been decisively separated by Burg \& Croxall [19] on the basis of independent genetic evidence and the two taxa can be separated by the colour of the iris. Of the Thalassarche cauta complex, they stated that the findings presented here justified the Taxonomy Working Group approach of treating them as two pairs of two taxa: T. cauta $+T$. steadi and $T$. salvini $+T$. eremita (Agreement on the Conservation of Albatrosses and Petrels [11]). The 'p' distances between pairs reflected this view, being around $1 \%$ between the pairs but only $0.2 \%$ between $T$. cauta and $T$. steadi and $0.3 \%$ between T. salvini and T. eremita.

We have pointed out above that the evidence provided by Burg \& Croxall [19] provides no information relevant to species level. And in terms of the criteria for species rank with allopatric taxa by Helbig et al. [38], namely that they are fully diagnosable in each of several discrete or continuously varying characters related to different functional contexts, melanophris and impavida should not be split solely on the basis of iris color. A small number of melanophris have been found breeding on Campbell Island, where more than 70,000 pairs of impavida breed. Chambers et al. [35], citing Moore et al. [39], claimed that they have recently been reported as breeding in sympatry on Campbell Island, but that they have distinct calls and mate assortatively, although they are capable of hybridizing when the sex ratio of one form is skewed. However, Moore et al. [39: 323] seemed to be less sure of what their data implied: “....at the Bull Rock South colony, $60 \%$ of melanophris found were paired with impavida.” In the abstract of Moore et al. [40: 334], it was stated: “...hybridization has occurred on Campbell Island at least as early as [1970]. Their presence [i.e. of dark-eyed $T$. impavida] suggests a low rate of interchange between the island groups, or recent immigration of T. melanophrys [sic melanophris] to Campbell Island and neighboring island groups.”. Given the very low numbers (to be expected given the philopatry of all albatross taxa), it appears that the data in the two papers by Moore et al. [39 and 40], and particularly 
the ratio of mixed to pure pairs at the Bull Rock South Colony, suggest that the two taxa can interbreed.

\section{THE RELEVANCE OF THE CRITERIA PROPOSED BY HELBIG ET AL. [47]}

It is interesting to consider how the accounts considered arguing for splits between taxa within Diomedea exulans, $D$. epomophora, Thalassarche melanophris, $T$. cauta and $T$. chlororhynchus compared with the criteria for species rank in Helbig et. al. [38]. In the critical passage in relation to allopatric taxa, they stated that predictions about possible reproductive isolation between allopatric taxa that differ only slightly (e.g. in size or darkness of plumage) are very uncertain. Such taxa are best treated as subspecies. With these considerations in mind, allopatric taxa should be assigned species rank if the sum of the character differences corresponds to or exceeds the level of divergence seen in related species that coexist in sympatry. To assess these criteria, a comparative analysis of related species is necessary Characters known to evolve quickly in response to latitude, climate or migration behavior must be regarded as less informative, e.g. differences in body size or proportions (such as wing length and shape), timing and number of broods per season, clutch size and moult patterns. Such characters frequently differ among populations and are thus less relevant taxonomically.

Judged by these criteria, few of the splits discussed above would be valid. What evidence might be relevant to these criteria? First, we have the genetic distances, based on complete mitochondrial cytochrome- $b$ sequences. In the absence of actual proof of introgression, there is no justification for ignoring these. A limitation of Penhallurick \& Wink [3] was that it relied on a single gene: cytochrome- $b$. It is obviously desirable to confirm these findings with studies of other, particularly nuclear, genes. But since the rate of evolution of cytochrome- $b$ is some ten times that of DNA in nuclear genes (cf. Brown et al. [41]), and since the cytochrome- $b$ distances between many albatross taxa are so low, it is unlikely that nuclear genes would show anything different. It should also be remembered that many studies have confirmed the utility of both cytochrome- $b$ and Bayesian inference. For example, May-Collado \& Agnarsson [42], in a study of cetacean phylogeny, found that a Bayesian phylogenetic analysis based on cytochrome- $b$ recovered all benchmark clades and for the first time supported Odontoceti monophyly based exclusively on analysis of a single mitochondrial gene.

The percentage distances between the species that were split by Robertson \& Nunn [1] are much smaller than those between previously recognized "good" species of albatross. For example, within the $D$. exulans complex, the distance between Robertson \& Nunn's [1] D. chionoptera [= nominate exulans] and D. antipodensis is $0.52 \%$; in the case of their $D$. exulans [= dabbenena], $0.87 \%$; and in the case of gibsoni, $0.52 \%$. D. gibsoni shows a percentage difference of $0.000 \%$ from $D$. antipodensis and $0.70 \%$ from dabbenena. Compare these nucleotide distances, all of less than $1.0 \%$, with the distances ranging from $3.2 \%$ to $3.6 \%$ between $D$. e. epomophora and D. e. sanfordi from all of the taxa in the exulans complex. We conclude that gibsoni, antipodensis and dabbenena are better recognized as subspecies of $D$. exulans than as good species in their own right. Both antipodensis and gibsoni were described as subspecies of $D$. exulans in their original description by Robertson \& Warham [43: 74 and 76].

Somewhat surprising is the distance evidence relating to D. amsterdamensis, which has generally been treated as a good species since its description as such by Roux et al. [15], although Bourne [44: 112, Table 4] treated it as a subspecies of $D$. exulans. The fact that it is only $0.52 \%$ distant from antipodensis, gibsoni and exulans, and only $0.87 \%$ removed from dabbenena strongly suggests that it belongs among the subspecies of exulans. There is additional evidence relevant to the status of amsterdamensis. The Amsterdam Albatross is said to differ from juvenile Wandering Albatrosses in the coloration of the bill. More is said on the similarity to the juvenile stage of exulans below. Amsterdam Albatrosses are supposed to have a diagnostic dark-brown cutting edge to the upper mandible, although this may appear black at a distance; and greenish-brown bill-tip, forming a dusky tip contrasting the rest of the bill (Marchant \& Higgins [45]). Lindsay Smith, president of the Southern Oceans Seabird Study Association, told me (pers. comm.) that there are specimens of antipodensis on Antipodes Island that are identical to specimens of $D$. amsterdamensis in terms of both plumage and bill marking. When a photograph of one of these birds was shown (withholding the knowledge of where the photo was taken) to Henri Weimerskirch, the great authority on Amsterdam Albatrosses, he unhesitatingly identified it as an Amsterdam Albatross. Given that the pairwise difference between $D$. epomophora and $D$. sanfordi is $0.09 \%$, it is difficult to claim that they are distinct species. The near identity of the cytochrome- $b$ sequences of these two taxa suggests that they must have diverged very recently in evolutionary terms, and that sanfordi is better retained as a subspecies of epomophora.

Turning to the genus Thalassarche: Chambers et al. [35] relied on a $1 \%$ level of sequence divergence as evidence of species status. While this certainly avoided the absurdities of claiming that a $0.09 \%$ distance was consistent with species status, it is essentially arbitrary. Why not $1.25 \%$, or $1.45 \%$ ? Tobias et al. [28] stated that to assess the species status of allopatric taxa using genetic differences, a comparison with distances between traditionally recognized species is necessary. The lowest percentage distance in terms of cytochrome$b$ between traditionally recognized species of Thalassarche is $1.66 \%$ between Thalassarche c. cauta and T. b. bulleri. Surely this is a better metric in deciding whether another pair of taxa within the same genus has reached the level of species, than a totally arbitrary $1.0 \%$ level as used by Chambers et al. [35].

Among the Yellow-nosed Albatross taxa, the distance of $0.35 \%$ between $T$. carteri $[=D$. bassi Mathews 1912] and $T$. chlororhynchos strongly suggests that carteri should also be treated as a subspecies of T. chlororhynchos. According to BirdLife International [8], very pale head distinguishes adults from more grey-headed Atlantic Yellow-nosed Albatross T. chlororhynchos. Juveniles difficult. In terms of Helbig et al.'s [38] requirement for assigning species status to allopatric taxa, as they are fully diagnosable in each of sev- 
eral discrete or continuously varying characters related to different functional contexts, this single feature separating carteri and chlororhynchos is insufficient. While slightly higher, the distance of $0.79 \%$ between $T$. impavida and $T$. melanophris, as opposed to much larger distances between melanophris and other traditionally recognized species of Thalassarche (1.92 \% in the case of chrysostoma; $2.80 \%$ in the case of cauta; $2.80 \%$ in the case of chlororhynchos; and $3.15 \%$ with bulleri) also suggests that impavida is better treated as a subspecies of T. melanophris.

The Tamura-Nei distances between taxa within the Thalassarche cauta complex range from $1.08 \%$ between $T$. cauta cauta and $T$. cauta eremita to $0.27 \%$ between $T$. cauta salvini and $T$. cauta eremita and $0.18 \%$ between T. c. cauta and T. c. steadi. It was pointed out above that the smallest gap between traditional species within Thalassarche was $1.66 \%$ between $T$. c. cauta and T. bulleri. The gap between $1.66 \%$ and $1.08 \%$ is the largest in the Thalassarche dataset. It seems sensible to treat this gap as that cut-off, taxa below which are subspecies, and taxa above which are separate species. Salvini and eremita have diverged furthest from nominate cauta among all the subspecies within the genus Thalassarche. But the distance data suggest that we treat them as semispecies, rather than full species. This is further supported by distances drawn from only those bases involved in amino acid triplets, which can be related directly to time of evolution (see Penhallurick \& Wink [3]). The amino acid distance between $T$. c. cauta and T. c. eremita is $0.26 \%$. In contrast, the amino acid distance between $T$. c. cauta and T. bulleri, which show the smallest TN distance of all traditional species within Thalassarche, was $0.53 \%$, more than twice as great.

\section{PLUMAGE DEVELOPMENT IN ALBATROSSES}

Since genetic distances alone are inadequate to justify splits, a consideration of plumage data follows. The following point will be made in this section: that very often, neoteny, that is the retention of either juvenile or intermediate plumage, is what differentiates related taxa. In the next section, these differences will be related to the different habitats occupied by different taxa within a group. And it will be suggested that these differences should be treated as ecophenotypic. And ecophenotypic differences generally should not be cited as evidence for species-level differentiation.

Note that the juvenile plumage of Diomedea exulans exulans is all chocolate brown (See Fig. 1) and this juvenile plumage applies to all taxa within the $D$. exulans complex. Male adult exulans are white with black trailing edge to wing and black band at the end of the tail. Females retain black plumage on upper-wings much later than males.

With adults of $D$. e. dabbenena, breeding males are largely white but retain black upperwings, and also differ from the nominate in having a smudged brown cap. Females have extensively brown plumage.

The adult of D. e. amsterdamensis is similar in appearance to the juvenile Wandering Albatross with uniform dark brown plumage, and a contrasting clown-like white mask extending from the top of the bill, behind the eyes, around the cheeks and under the chin, and white underwings. A gen-

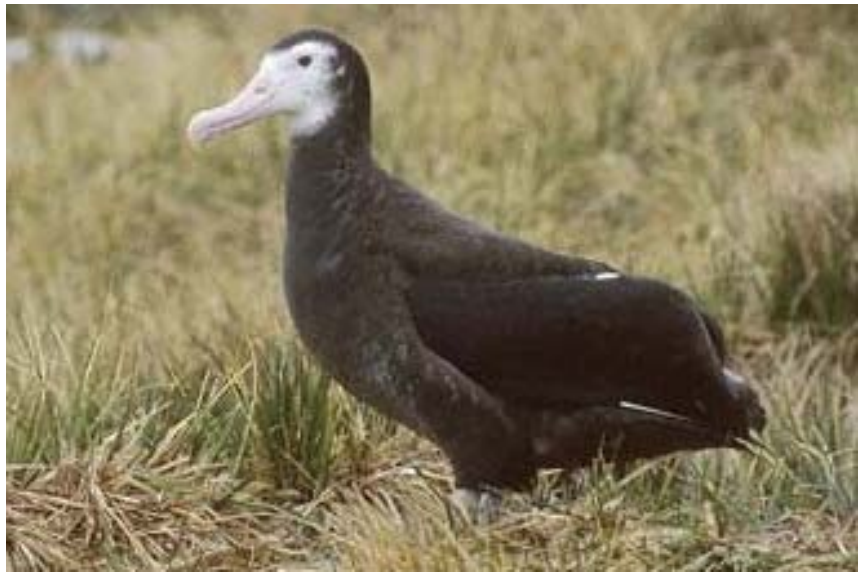

Fig. (1). Juvenile Diomedea exulans exulans South Georgia [photo John Penhallurick].

eral comment that might be made about the taxa within the D. exulans complex breeding in New Zealand (antipodensis and gibsoni) is that their plumages resemble that of the nominate; but the snowy plumage of the nominate is seldom, and perhaps never, attained. Breeding begins in darker plumages cf. Marchant \& Higgins [45: 279]

If we turn next to Diomedea epomophora, Fig. (2) shows dorsal views of both juvenile $D$. e. epomophora and juvenile $D$. e. sanfordi. The two plumages are very similar: sanfordi has slightly denser black and white mottling on the mantle, but both taxa have all black upperwings. In the fully adult plumage, both taxa lose the mottling on the mantle, but sanfordi retains the black upperwings, while in the nominate, black is retained only as a narrow training edge in the tertiaries and secondaries, and largely black primaries. We find differences in the climates on breeding islands similar to those seen with taxa in the exulans complex: D. e. sanfordi
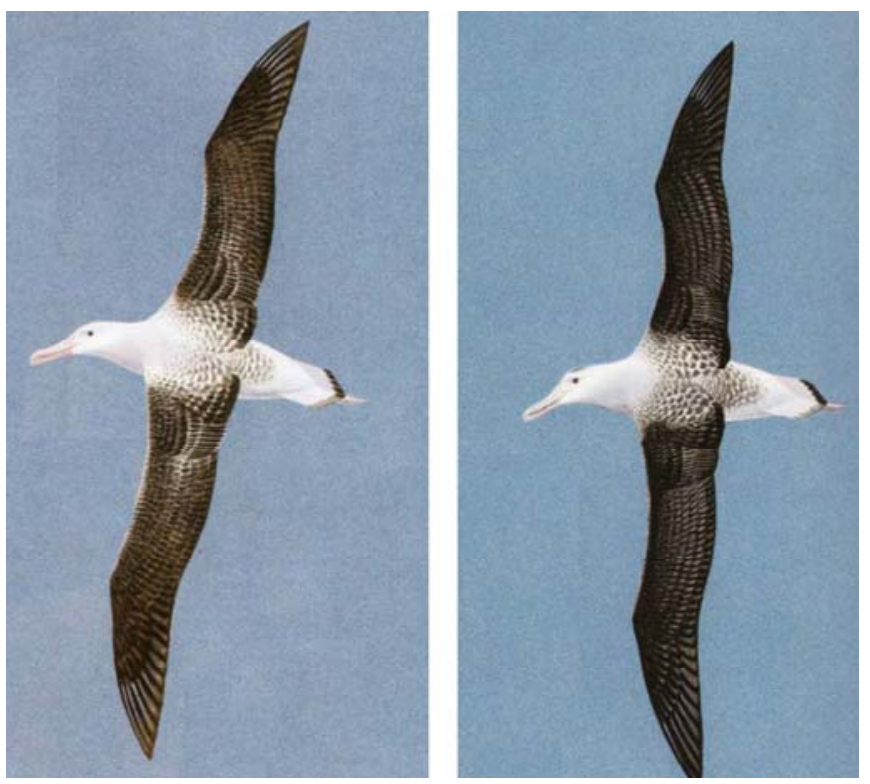

Fig. (2). Dorsal plumage of juvenile Diomedea epomophora (left figure) and of juvenile Diomedea epomophora sanfordi (right figure) [Taken from plates in Marchant \& Higgins [45]]. 
breeds on Taiaroa Head where the mean temperature varies from $13.2^{\circ} \mathrm{C}$ in January to $7.0^{\circ} \mathrm{C}$ in July; and on the Chatham Islands, where the mean annual air temperature is around $11.0^{\circ} \mathrm{C}$. In contrast, nominate epomophora breeds on Enderby Island and on Auckland Islands and Adams Island, with a mean annual average temperature of $8^{\circ} \mathrm{C}$; on Campbell Island, with a mean annual temperature of $6^{\circ} \mathrm{C}$. In other words, the taxon breeding in warmer climates retains all black upperwings, while that breeding in cooler climates develops largely white upperwings.

Consider next plumage differences in the various species complexes within Thalassarche, beginning with T. melanophris. The juvenile plumage of Thalassarche melanophris impavida can be distinguished from the juvenile nominate by darker underwings; but they are best distinguished by the extent of a dark brow and the color of the iris, though many juvenile impavida are not safely separable, as iris and brow are little different (Marchant \& Higgins [45: 290-291]. Adult impavida differ from the nominate in heavier black brow (more extensive in front of eye) and honey-colored (not dark-brown) iris; slightly broader black leading edge on underwing; series of bold, dark streaks (formed by greyish black subhumerals) run off elbow (nearly reaching trailing edge) and extend inwards to base of wing, isolating white patch (formed by white subhumeral coverts) in center of wing-pit. Though the differences are not great, once again we find that the darker taxon, impavida breeds in the subantarctic islands of New Zealand, while the main breeding grounds of melanophris are much further south, either below the Antarctic Convergence (South Georgia, Heard and MacDonald Islands); or on the Convergence (Kerguelen); or just north of the convergence (Falklands, Crozet Island, Macquarie Island). Within the T. cauta complex: BirdLife International [8] commented under $T$. cauta that a very similar White-capped albatross $T$. steadi is slightly larger and has a paler face and less yellow on the culmen of the bill. In view of the requirements of Helbig et. al. [38], and the comments of Chambers et al. [35], this must surely be one of the least defensible splits from T. cauta, and clearly motivated by conservation concerns, not any scientific evidence. However, unlike the other cases discussed so far, plumage differences between taxa in the $\mathrm{T}$. cauta complex do not seem to correlate with annual mean temperature at their breeding stations.

Plumage differences between the other taxa concentrate on the plumage of the head. There are significant similarities between the three taxa at various stages of development. There is at least one feature which links the immature plumage of cauta with the adult plumage of salvini and eremita: notably the black subterminal spot formed by the black mandibular unguis. Marchant \& Higgins [45] point out the extensive overlap between immature salvini and immature cauta: namely that most have full grey hood (matching darkestheaded cauta) though some paler, matching intermediate cauta and describe salvini as "Like nominate [i.e. cauta]".

Generally speaking, the plumage of the head in the three taxa goes from the lightest cauta, with salvini in the middle and eremita the darkest. Again, this looks like ecophenotypic variation. Also, it is clear that there are a number of stages where the three taxa are not noticeably different. Also, remember that Helbig et. al. [38] stated that taxa should be distinguished at the species level only if they are fully diagnosable in each of several discrete or continuously varying characters related to different functional contexts. The variation in head color which distinguishes the taxa in the T. cauta complex falls short here.

People living in warmer climates are accustomed to thinking that white garments are preferable to black ones because white reflects light and heat better, while black absorbs it more readily. But how do we square this with the fact that a number of birds living in the very cold conditions of the high Arctic and the high Antarctic have all-white plumage (e.g. Ivory Gull Pagophila eburnea (Phipps 1774) in the Arctic; and Snow Petrel Pagodroma nivea (J. R. Forster 1777) in the Antarctic)? Furthermore, with a number of species we find paler morph birds breeding in the colder part of the range while dark morphs are more common in the warmer regions. Mundy [46] has discussed this in relation to Parasitic Jaeger Stercorarius parasiticus (Linnaeus 1758), a species which has a holarctic distribution. Mundy [46] pointed out that they show a north-south cline in morph frequency with melanistic birds commoner in the south of the range. We also have Gloger's Rule, which states that within a species of endotherms, more heavily pigmented forms tend to be found in more humid environments, e.g. near the equator. In the case of birds, a major factor appears to be the increased resistance of dark feathers to feather-degrading bacteria. Feathers in humid environments have a greater bacterial load, and humid environments are more suitable for microbial growth; dark feathers are more difficult to break down (Burtt \& Ichida [47]). Another explanation as to why white plumage appears to have advantages in cold conditions is that white plumage can keep a bird warmer. The fact that the white feather barbule is hollow reduces the conductivity of the plumage. Thus, there may indeed be a physical reason for the better insulation of white birds (Marchand [48]). In conclusion, there appear to be several environmental factors encouraging paler plumage in colder climates.

This paper has provided an ecophenotypic explanation for the variation in plumage of the various albatross taxa under discussion. And as in the case of variation in Stercorarius parasiticus, mentioned above, ecophenotypic variation can occur within a single species, and should not be taken as evidence that we are dealing with multiple species.

\section{POSSIBLE MECHANISMS FOR ECOPHENOTYPIC VARIATION}

At this stage, it is only possible to speculate on possible mechanisms behind the ecophenotypic variation among albatross taxa. Plumage development is controlled by genes: Mundy et al.[49] have found that a single locus, the melanocortin-1 receptor (MC1R) locus, is responsible for melanic polymorphisms in at least three unrelated species: the Bananaquit Coereba flaveola (Linnaeus 1758), the Snow Goose Anser caerulescens (Linnaeus 1758) and the Parasitic Jaeger Stercorarius parasiticus (Linnaeus 1758). So the mechanism for ecophenotypic variation must involve either changes to genes or to the timing and/or expression of genes. An obvi- 
ous candidate in the case of changes to the expression of genes is epigenetics. The modern usage of "epigenetics" in scientific discourse refers to heritable traits (over rounds of cell division and sometimes transgenerationally) that do not involve changes to the underlying DNA sequence. (Russo et al. [50]).

Epigenetics refers to all modifications to genes other than changes in the DNA sequence itself. Epigenetic modifycations include addition of molecules, like methyl groups, to the DNA backbone. Adding these groups changes the appearance and structure of DNA, altering how a gene can interact with important interpreting (transcribing) molecules in the cell's nucleus. Genes carry the blueprints to make proteins in the cell. The DNA sequence of a gene is transcribed into RNA, which is then translated into the sequence of a protein. Every cell in the body has the same genetic information; what makes cells, tissues and organs different is that different sets of genes are turned on or expressed. Because they change how genes can interact with the cell's transcribing machinery, epigenetic modifications, or "marks", generally turn genes on or off, allowing or preventing the gene from being used to make a protein. It should be stressed that epigenetic changes can be a response to environmental pressures, and that, as shown in the case of humans, they can develop very rapidly (e.g. Kaati et al. [51]). Epigenetic changes are not necessarily confined to one generation, but can be inherited through successive generations. It should also be conceded that purely epigenetic changes can rarely lead to species level differences between taxa, as in the case of fish that use electroreception (Hopkins [52]).

Some general principles of epigenetics strongly suggest such mechanisms might well be responsible for plumage variation among most albatross complexes. Most epigenetic changes do not involve any sort of speciation or reproductive isolation. It should be pointed out that sex differences in plumage colouring must be epigenetic, because it is very unlikely that there are colour genes on the female-specific $\mathrm{W}$ chromosome. There are certainly none in the chicken for which the genome has been sequenced (J. Graves, pers. comm., June 26, 2010). Also, it has been widely conceded that plumage variation with albatross complexes is due to neoteny and that ontogeny is primarily under the control of epigenetic mechanisms. According to Graves (loc.cit.): "a difference between juveniles and adults must be epigenetic at some level (that is the colour genes are present, but expressed only in the juvenile)." Given that more northerly taxon in the case of the $D$. epomophora complexes retains aspects of juvenile plumage into adulthood, we can see that for environmental reasons white plumage is favoured in colder, and dark plumage in warmer climates. The simplest explanation here is that in the case of the more northerly breeding sanfordi , methylation. has blocked that part of the transition to adult plumage that leads to whitening of the tertiary and secondary feathers.

There are different kinds of epigenetic 'marks', chemical additions to the genetic sequence. The addition of methyl groups to the DNA backbone is used in some genes to distinguish the gene copy inherited from the father and that in- herited from the mother. In this situation, known as "imprinting”, the marks both distinguish the gene copies and tell the cell which copy to use to make proteins. Imprinted genes do not rely on traditional laws of Mendelian genetics, which describe the inheritance of traits as either dominant or recessive. The impact of an imprinted gene copy, however, depends only on which parent it it inherited from. For some imprinted genes, the cell uses only the copy from the mother to make proteins, and for others only that from the father. (Johns Hopkins Medicine [53]).

Within the Diomedea exulans complex, dabbenena shows very significant sexual dimorphism: adult males have almost white plumage with a dark smudge on the crown and black upperwings, while most females retain dark, neotenous plumage as adults. These different plumages may relate to different environmental pressures, as males head south from Gough Island to feed, while females move north to feed. The differential plumage in the female most likely has an epigenetic basis, due to the apparent absence of any color genes on the female-specific W-chromosome. Thus, it is possible that methylation must stop or retard the development of whiter, adult plumage in the female. If we assume that these plumage patterns were characteristic of the common ancestor of all the exulans complex, then the extensive whiteness of both male and female nominate exulans could involve imprinting of the male epigenetic inheritance. On the other hand, the two taxa on the New Zealand subantarctic islands, antipodensis and gibsoni retain neotenous dark plumage well into adulthood, as does amsterdamensis. Above, Rheindt actually listed the "extreme neoteny" of amsterdamensis as a reason for granting it full species status. But since this phenomenon is likely to be due to epigenetic mechanisms, and those mechanisms are ecophenotypic, his argument fails. As all these taxa breed in a significantly warmer climate, where dark plumage confers advantages, there would be environmental pressure to imprint the female epigenetic inheritance.

The main plumage difference between the southern Thalassarche melanophris melanophris and the more northern $T$. $m$. impavida was that the northern birds had somewhat darker plumage. This difference is consistent with environmental pressures and it is reasonable to assume that the marginally darker plumage of both male and female impavida is because of epigenetics partially restricting development to the whiter fully adult plumage of the nominate.

In conclusion, it should be stressed that the claim that all plumage color variation is due to epigenetics is NOT being made here. However, another obvious case of neoteny, which again suggests an epigenetic explanation, is Sandford's Fish-Eagle Haeliaeetus sanfordi Mayr, 1935 of the Solomon Islands. The plumage of this taxon is identical to the juvenile plumage of White-bellied Sea-Eagle Haliaeetus leucogaster (J.F.Gmelin,1788). Given that Wink et al. [54] found that by studying the cytochrome- $b$ gene of mtDNA that sanfordi differed from leucogaster by only $0.3 \%$, far below the $1.6 \%$ that otherwise appears to lower the limit for species recognition within Haeliaeetus, it seems likely it should become a subspecies of Haliaeetus leucogaster. In conclusion, the investigation of epigenetic markers in avian 
DNA might do much to reveal various mechanisms leading to different plumages in related taxa.

\section{ACKNOWLEDGEMENTS}

Thanks are due to Professor Jennifer Graves, Head of the Comparative Genomics Research Group in the Research School of Biology, The Australian National University. They are also due to Professor Les Christidis, Director, National Marine Science Centre School of Environment, Science and Engineering, Southern Cross University

\section{CONFLICT OF INTEREST}

None declared.

\section{REFERENCES}

[1] Robertson CJR, Nunn GB. Towards a new taxonomy for albatrosses. In: Robertson G, Gales R, Eds. Albatross biology and conservation. Chipping Norton: Beatty and Sons 1998; pp. 13-9.

[2] Nunn GB, Cooper J, Jouventin P, Robertson CJR, Robertson GG. Evolutionary relationships among extant albatrosses (Procellariiformes: Diomedeidae) established from complete cytochrome b gene sequences. Auk 1996; 113: 784-801.

[3] Penhallurick JM, Wink M. Analysis of the taxonomy and nomenclature of the Procellariiformes based on complete nucleotide sequences of the mitochondrial cytochrome- $b$ gene. Emu 2004; 104: 125-47.

[4] Haffer J. Species concepts and species limits in ornithology. In: del Hoyo J, Elliott A, Sargatal J, Eds. Handbook of the birds of the world. Vol. 4, Sandgrouse to Cuckoos. Barcelona: Lynx Edicions 1997; pp. 11-24.

[5] Mayr E. What is a species, and what is not? Philos Sci 1996; 63: 262-77.

[6] International Ornithologists' Congress. IOC World Bird List Version 2.4. 2010. Available from: http://www.worldbirdnames.org/ [Accessed June 30, 2010].

[7] BirdLife International. Species of Diomedea. 2010. Available from: http://www.birdlife.org/datazone/species/index.html?action=SpcH TMFindResults.asp\&hdnAction=SEARCH\&hdnPageMode $=0$ \&cboFamily=-2\&txtGenus=Diomedea\&txtSpecies=\&txtCommonName=\&cboRegion=-2\&cboCountry=-2 [Accessed June 202010 ].

[8] BirdLife International. Species of Thalassarche. 2010b. Available from: http://www.birdlife.org/datazone/species/index.html?action= SpcHTMFindResults.asp\&hdnAction=SEARCH\&hdnPageMode=$0 \&$ cboFamily $=-2 \&$ txtGenus $=$ Thalassarche\&txtSpecies $=$ \&txtCommonName $=\&$ cboRegion $=-2 \&$ cboCountry $=-2$ [Accessed June 20 2010]

[9] Christidis L, Boles WE. Systematics and taxonomy of Australian birds. Collingwood, Vic.: CSIRO Publishing 2008.

[10] Australian Government Department of the Environment, Water, Heritage and the Arts Threatened species \& ecological communities. 2010. Available from: http://www.environment.gov. au/biodiversity/threatened/index.html [Accessed 3 July 2010].

[11] Agreement on the Conservation of Albatrosses and Petrels. Data Portal. 2010. Available from: http://data.acap.aq/ [Accessed 3 July 2010]

[12] Navarro-Sigüenza AG, Peterson AT. An alternative species taxonomy of the birds of Mexico. Biota Neotropica 2004; 4 (2): 1-32.

[13] Rojas-Salto OR, Navarro-Sigüenza AG, Espinosa de los Monteros A. Systematics and bird conservation policies: the importance of species limits. Bird Conserv Int 2010; 20: 176-85.

[14] Garnett ST, Christidis L. Implications of changing species definitions for conservation purposes. Bird Conserv Int 2007; 17: 187-95.

[15] Roux J-P, Jouventin P, Stahl JC, Weimerskirch H. Un nouvel albatross Diomedea amsterdamensis n.sp. Découvert sur l'ile Amsterdam(37 50’ S, 77³5’ E). L’Oiseau Rev fr Orn 1983; 53:1-11.

[16] Tickell WLN. Albatrosses. Sussex: Pica Press 2000.

[17] Brooke M. Albatrosses and petrels across the world. Oxford, New York: Oxford University Press 2004.

[18] Onley DJ. Field guide to the albatrosses, petrels and shearwaters of the world. London: Christopher Helm 2007.
[19] Burg TM, Croxall JP. Global relationships amongst black-browed and grey-headed albatrosses: analysis of population structure using mitochondrial DNA and microsatellites. Mol Ecol 2001; 10: 264760.

[20] Burg TM, Croxall JP. Global population structure and taxonomy of the wandering albatross species complex. Mol Ecol 2004; 13: 2345-55.

[21] Rheindt FE, Austin JJ. Major analytical and conceptual shortcomings in a recent revision of the Procellariiformes - a reply to Penhallurick \& Wink (2004). Emu 2005; 105: 181-6.

[22] Abbott CL, Double MC. Phylogeography of shy and white-capped albatrosses inferred from mitochondrial DNA sequences: implications for population history and taxonomy. Mol Ecol 2003; 12 : 2747-58.

[23] Abbott CL, Double MC. Genetic structure, conservation genetics and evidence of speciation by range expansion in shy and whitecapped albatrosses. Mol Ecol 2003; 12: 2953-62.

[24] Moritz C. Defining 'evolutionarily significant units' for conservation. Trends Ecol Evol (Amst) 1994a; 9: 373-4.

[25] Moritz C. Applications of mitochondrial DNA analysis in conservation: a critical review. Mol Ecol 1994b; 3: 401-11.

[26] Avise JC, Wollenberg K. Phylogenetics and the origin of species. Proc Natl Acad Sci USA 1997; 94: 7748-55.

[27] Howell N, Elson JL, Howell C, Turnbull DM. Relative rates of evolution in the coding and control regions of african mtDNAs. Mol Biol Evol 2007; 24 (10): 2213-21.

[28] Tobias JA, Seddon N, Spottiswood CN, Pilgrim JD, Fishpool LDC, Collar NJ. Quantitative criteria for species delimitation. Ibis 2010; 152 (4): 724-46.

[29] Rains D, Weimerskirche H, Burg TM. Piecing together the global population puzzle of wandering albatrosses: genetic analysis of the Amsterdam albatross Diomedea amsterdamensis. J Avian Biol 2011; 42: 69-79.

[30] Eda M, Koike H, Kuro-o M, Mihara S, Hasegawa H, Higuchi H. Inferring the ancient population structure of the vulnerable albatross Phoebastria albatrus, combining ancient DNA, stable isotope, and morphometric analyses of archaeological samples. Conserv Genet 2012; 13: 143-51.

[31] Remsen JV. Proposal 388 to South American Classification Committee: Split Diomedea exulans into four species. 2010. Available from: http://www.museum.lsu.edu/ Remsen/SACCprop388.html [Accessed June 18 2010].

[32] Johnson KP, Sorenson MD. Phylogeny and biogeography of dabbling ducks (genus Anas): a comparison of molecular and morphological evidence. Auk 1999; 116 (3): 792-805.

[33] Liebers D, de Knijff P, Helbig AJ. The herring gull complex is not a ring species. Proc Biol Sci 2004; 271 (1542): 893-901.

[34] Mank JE, Carlson JE, Brittingham MC. A century of hybridization: decreasing genetic distance between American Black Ducks and Mallards. Conserv Genet 2004; 5: 394-403.

[35] Chambers GK, Moeke C, Steel R, Trueman JWH. Phylogenetic analysis of the 24 named albatross taxa based on full mitochondrial cytochrome b DNA sequences. Notornis 2009; 56(2): 82-94.

[36] Stoeckle M. Taxonomy, DNA and the bar code of life. Bioscience 2001; 53: 796-7.

[37] Edwards JL. Consortium for the barcode of life: An introduction. Genes Genet Syst 2005; 80 (6): 443.

[38] Helbig AS, Knox AG, Parkin DT, Sangster G, Collinson M. Guidelines for assigning species rank. Ibis 2002; 144: 518-25.

[39] Moore PJ, Taylor GA, Amey JM. Interbreeding of Black-browed Albatross Diomedea m. melanophris and New Zealand Blackbrowed Albatross D. m. impavida on Campbell Island. Emu 1997; 97: 322-4.

[40] Moore PJ, Burg TM, Taylor GA, Millar CD. Provenance and sex ratios of Black-browed Albatross Thalassarche melanophrys[sic], breeding on Campbell Island, New Zealand. Emu 2001; 101 (4): 329-34.

[41] Brown WM, George M Jr., Wilson AC. Rapid evolution of animal mitochondrial DNA. Proc Natl Acad Sci USA 1979; 76 (4): 196771.

[42] May-Collado LM, Agnarsson I. Cytochrome $b$ and Bayesian inference of whale phylogeny. Mol Phylogenet Evol 2006; 38: 344-54

[43] Robertson CJR, Warham J. Nomenclature of the New Zealand Wandering Albatross Diomedea exulans. Bull Br Ornithol Club 1992; 112: 74-81. 
[44] Bourne WRP. The evolution, classification and nomenclature of the great albatrosses. Le Gerfaut 1989; 79:105-16.

[45] Marchant S, Higgins PJ, Eds Handbook of Australian, New Zealand and Antarctic birds. Vol.1, Part A: Ratites to Petrels. Melbourne: Oxford University Press 1990.

[46] Mundy NI. A window on the genetics of evolution: MC1R and plumage colouration in birds. Proc Biol Sci 2005; 272 (1573): 1633-40.

[47] Burtt EH Jr., Ichida JM. Gloger's Rule, feather-degrading bacteria, and color variation among Song Sparrows. Condor 2004; 106(3): 681-6.

[48] Marchand PJ. Life in the cold: an introduction to winter ecology. Hanover, NH: University Press of New England 1996.

[49] Mundy NI, Badcock NS, Hart T, Scribner K, Janssen K, Nadeau NJ. Conserved genetic basis of a quantitative plumage trait involved in mate choice. Science 2004; 303 (5665): 1870-3.
[50] Russo VEA, Martienssen RA, Riggs AD. Epigenetic mechanisms of gene regulation. Plainview, NY.: Cold Spring Harbor Laboratory Press 1996.

[51] Kaati G, Bygren LO, Pembrey M, Sjöström M. Transgenerational response to nutrition, early life circumstances and longevity. Eur J Hum Genet 2007; 15(7): 784-90.

[52] Hopkins CD. Signal evolution in electric communication. In: Hauser MD, Konishi M, Eds. The design of animal communication. Cambridge, MA: M. I. T. Press 1999; pp. 461-91.

[53] Johns Hopkins Medicine. Backgrounder: Epigenetics and Imprinted Genes 2002. Available from: http://www.hopkinsmedicine org/press/2002/november/epigenetics.htm [Accessed July 4 2010]

[54] Wink M, Heidrich P, Fentzloff CA. mtDNA phylogeny of sea eagles (genus Haliaeetus) based on nucleotide sequences of the cytochrome $b$ gene. Biochem Syst Ecol 1996; 24: 783-91.

(C) John Penhallurick; Licensee Bentham Open.

This is an open access article licensed under the terms of the Creative Commons Attribution Non-Commercial License (http://creativecommons.org/ licenses/by-nc/3.0/), which permits unrestricted, non-commercial use, distribution and reproduction in any medium, provided the work is properly cited. 